\title{
Relict Communities for Monitoring Park Ecosystems in Glen Canyon National RECREATION AREA
}

\author{
Jack L. Butler $\uparrow$ Brian S. Bich $\uparrow$ Cheryl A. Schmidt \\ Department of Biology $\uparrow$ The UnIVERSITY of SOUTH Dakota \\ VERMILLION
}

Grazing by domestic livestock is authorized in Glen Canyon National Recreation Area and continues on about 80 percent of the park. Concern over competing land uses has generated considerable interest in the direct and indirect effects of grazing on vegetation, small mammal, and avian community structure and function. The primary objectives of this study are:

1. to identify and evaluate the abiotic and biotic factors influencing the structure and species composition of relict and grazed pinyon-juniper and blackbrush/Indian ricegrass communities, and

2. to select, refine and validate a system that can be used to field monitor condition and trend of relict and grazed communities.

It is the goal of this project to develop a method of qualitatively assessing and monitoring community condition and trend using a combination of quantitative community attributes which are sensitive to grazing by domestic livestock; and which can be easily implemented and interpreted within the management objectives of GCNRA.
The 1989 field season was limited to an initial aerial and ground reconnaissance of a relict pinyonjuniper community on the South Block and several grazed pinyon-juniper communities on the Orange Cliffs. A preliminary survey of blackbrush/ricegrass grazed and relict areas was conducted early in the 1990 field season. Four study sites within the blackbrush/ Indian ricegrass vegetation type that best represented the end product of four grazing regimes (relictungrazed, light, moderate, and heavy) were selected for detailed study. Selected blackbrush/Indian ricegrass communities are found on the area known as Grand Bench while the pinyon-juniper communities are located on the Orange Cliffs. Distance from water, degree of slope, and the extent of physical evidence of livestock (degree of soil disturbance, number and extent of trails, presence of feces) were the criteria that were used to classify a site as either being lightly, moderately or heavily grazed by livestock. After reconnoitering the Orange Cliffs area, it was estimated that the pinyon-juniper communities throughout the area had been strongly affected by the activities of domestic livestock. Two sites in western Canyonlands National Park were considered for inclusion as relict and/or lightly grazed sites, but proved to have been 
either disturbed by livestock in the past or located on a significantly different substrate. Therefore, relict and/ or lightly grazed pinyon-juniper sites could not be located during the 1990 field season.

Four belt-transects, 2 x $50 \mathrm{~m}$, were systematically placed within each of the four sites for each community type. Canopy cover for the tree (individuals $\geq 2.0 \mathrm{~m}$ in height) and shrub (individuals $<2.0 \mathrm{~m}$ in height) strata were estimated by line intercept. Shrub and tree density were estimated by counting the number of individuals rooting within each belt transect. The herbaceous vegetation was evaluated from a $45 \times 120 \mathrm{~m}$ macroplot permanently placed on each study site. The macroplot consisted of four parallel $45 \mathrm{~m}$ transects spaced $30 \mathrm{~m}$ apart. Fifty $50 \mathrm{x}$ $100 \mathrm{~cm}$ quadrats were placed contiguously along each transect beginning $10 \mathrm{~m}$ from one end of the transect and ending $10 \mathrm{~m}$ from the other end. Basal area of the major species were estimated for each site by placing each individual plant occurring within each quadrat into one of seven size classes: $1=0-0.5 \mathrm{~cm}^{2}$ (primarily small, single stemmed individuals), $2=0.6-5 \mathrm{~cm}^{2}, 3=6$ $15 \mathrm{~cm}^{2}, 4=16-50 \mathrm{~cm}^{2}, 5=51-150 \mathrm{~cm}^{2}, 6=151-300 \mathrm{~cm}^{2}$, $7=\geq 300 \mathrm{~cm}^{2}$. Using the above size classes, rather than individually estimating percent basal cover, reduced subjectivity in the sampling procedure. Size class distribution, of different species within a series of quadrats, is assumed to represent the probable replacement series during succession or retrogression.

A $100 \times 100 \mathrm{~m}$ grid of Sherman live traps $(7.5 \mathrm{~cm}$ x $8.8 \mathrm{~cm} \times 22.5 \mathrm{~cm}$ ) was established at each selected study site. Traps were arranged in a $10 \times 10$ square with $10 \mathrm{~m}$ spacing between trap stations. Preliminary trapping indicated that four trap-nights were required to adequately sample the resident small mammal populations on Grand Bench. However, trapping may be extended to five or six nights on the Orange Cliffs for the 1991 field season. Traps were opened and baited approximately one hour before dark, and were checked and closed within two hours of daylight. Upon initial capture, each individual was toe-clipped for unique identification, and the following information recorded: toe-clip number, species, sex, age class (based on pelage), length of tail, length of hindfoot, reproductive condition, and general condition. As soon as all data were recorded, each individual was released at the point of capture and observed until lost from sight. Data from the markrecapture will be treated as a nested grid (Humphrey 1988, Otis et al. 1978), in conjunction with the markrecapture data analysis package CAPTURE available from Gary C. White at Colorado State University, to estimate species composition, population density, age structure, and sex ratio of the small mammal populations at each site.

The avian community was sampled by walking along a prescribed $1000 \mathrm{~m}$ route on each study site. No attempt was made to estimate actual densities of bird populations, but the censuses should provide information on relative abundances. Having developed some familiarity with the communities during the summer of 1990, a method of estimating actual bird population densities may be implemented during the 1991 field season.

Data are currently being compiled for analysis. Similarity indices (Mueller-Dombois and Ellenberg 1974) will be calculated to objectively compare vegetation on the four study sites in relation to the grazing gradient. Sorensen's index will be calculated to provide a qualitative measure of similarity while Ellenberg's Community Coefficient will be used to provide a quantitative measure. Sorensen's index of similarity gives equal weight to the presence or absence of all species recorded at each site, while Ellenberg's community coefficient is weighted toward the more abundant species (Mueller-Dombois and Ellenberg 1974). A comparison of the two similarity coefficients may provide an indication of the relative contribution of both rare and abundant species. A diversity profile will also be constructed for each sampled community as described by Swindel et al. (1987) and Lewis et al. (1988). Diversity profiles provide an index free method of graphically illustrating the intrinsic diversity between two communities. Diversity profiles are unaffected by the size of the community or by the size or abundance of the plants (Lewis et al. 1988).

The overall goal in data interpretation is to identify a community characteristic or a set of community characteristics that is sensitive to grazing and an additional set of characteristics that demonstrates grazing resistance. The index will combine information on vegetation and wildlife and will define the upper and lower limits of community responses to grazing by domestic livestock. The series of 400 quadrats that will be sampled along a grazing gradient of ungrazed, lightly grazed, moderately grazed, and heavily grazed (100 quadrats per site) should reflect the entire array of desirable and undesirable situations that may be encountered. Averaging the values recorded from the 100 quadrats 
at each site assumes no within-site variation. Therefore, the various combinations of community attributes recorded from all 400 quadrats will be used to characterize each site for each vegetation type, as described by Ratliff and Westfall (1989). The technique allows the classification and ordination of species, quadrats and communities. The factor or factors which best reflect and account for differences among the grazed and ungrazed sites will be identified and used to evaluate change over time. The procedure recognizes within-site variation for the various community attributes. However, within site attributes can easily be averaged for site characterization.

\section{$\downarrow \quad$ Literature Cited}

Lewis, C.E., B.F. Swindel, and G.W. Tanner. 1988. Species diversity and diversity profiles: concept, measurement, and application to timber and range management. J. Range Manage. 41:466-469.
Mueller-Dombois, D., and H. Ellenberg. 1974. Aims and methods of vegetation ecology. John Wiley and Sons, New York, New York, USA.

Ratliff, R.D., and S.E. Westfall. 1989. Monitoring plant community change: an application of quadrat classification and discriminant analysis. Vegetatio 80:1-9.

Swindel, B.F., L.F. Conde, and J.E. Smith. 1987. Index-free diversity orderings: concept, measurement, and observed response to clear 